\title{
Penegakan Hukum Terhadap Pertambangan Emas Tanpa Izin oleh Kepolisian Sektor Kecamatan Singingi
}

\author{
Hana Aulia Putri \\ Magister Ilmu Hukum Universitas Islam Indonesia Yogyakarta Indonesia \\ Jln. Cik Di Tiro No. 1, Yogyakarta, Indonesia 55223 \\ hana_auliaputri22@yahoo.com
}

\begin{abstract}
Unlicensde gold mining still occurs very often in Singingi District, leading to negative impacts on the environment. This research was conducted to determine the law enforcement against unlicensed gold mining (PETI) by the Singingi District Police and the obstacles. This is an empirical juridical or sociological legal research carried out by identifying the law and how the effectiveness of the law applies. The results conclude that the efforts made in the context of law enforcement of the PETI crime are preventive and repressive efforts. However, these law enforcement efforts have obstacles that cause ineffective PETI law enforcement by the Singingi District Police, namely the lack of supporting facilities and infrastructure, lack of coordination, both between the government and the community, and the lack of enforcement of existing indigenous law.
\end{abstract}

Key Words: Law enforcement; unlisenced gold mining

\begin{abstract}
Abstrak
Penambangan emas yang dilakukan tanpa izin masih sering terjadi di Kecamatan Singingi sehingga menimbulkan dampak negatif bagi lingkungan hidup. Penelitian ini dilakukan untuk mengetahui penegakan hukum terhadap pertambangan emas tanpa izin (PETI) oleh Kepolisian Sektor Kecamatan Singingi dan hambatannya. Penelitian ini merupakan penelitian yuridis empiris atau penelitian hukum sosiologis yaitu yang dilakukan dengan cara mengadakan identifikasi hukum dan bagamana efektifitas hukum itu berlaku. Hasil penelitian ini menyimpulkan bahwa upaya yang dilakukan dalam rangka penegakan hukum tindak pidana PETI tersebut yaitu upaya preventif dan represif. Akan tetapi, upaya penegakan hukum tersebut memiliki hambatan-hambatan yang menyebabkan tidak efektifnya penegakan hukum PETI oleh Kepolisian Sektor Kecamatan Singingi, yaitu kurangnya pendukung sarana dan prasarana, kurangnya koordinasi, baik antara pemerintah dan masyarakat, serta kurang tegaknya hukum adat yang ada.
\end{abstract}

Kata-kata Kunci: Penegakan hukum; pertambangan emas tanpa izin 


\section{Pendahuluan}

Undang-Undang Dasar (UUD) 1945 menegaskan bahwa Negara Indonesia berdasarkan atas hukum (Rechtstaat), tidak berdasarkan atas kekuasaan belaka (Machstaat). Hal ini berarti bahwa Republik Indonesia adalah negara hukum yang demokratis berdasarkan Pancasila dan UUD 1945, menjunjung tinggi hak asasi manusia, dan menjamin semua warga negara bersamaan kedudukannya di dalam hukum dan pemerintahan serta wajib menjunjung hukum dan pemerintahan itu dengan tidak ada kecualinya. ${ }^{1}$ Makin majunya masyarakat, makin berkembangnya teknologi, makin pesatnya pertambahan penduduk berakibat makin terlihatnya kepentingan hukum di dalam masyarakat luas. Didalam menjalin hubungan satu sama lain orang harus mengetahui kedudukan, hak dan kewajibannya sebagai anggota masyarakat. Setiap orang wajib mengetahui perbuatan mana yang hendak dibenarkan oleh Undang-Undang (rechtshandeling) dan perbuatan mana yang merupakan onrechtmatige daad (perbuatan melanggar hukum). ${ }^{2}$

Hukum dalam mencapai tujuannya harus mencerminkan keadilan. Adil pada hakekatnya berarti memberikan atau memperlakukan seseorang atau pihak lain sesuai dengan apa yang menjadi haknya. ${ }^{3}$ Di dalam pergaulan hidup, manusia memiliki patokan-patokan sendiri untuk mencapai tujuan hidupnya, akan tetapi patokan-patokan itu seringkali bertentangan antara satu individu dengan individu lain. ${ }^{4}$ Kesadaran hukum sebagai buah dari budaya hukum dapat menimbulkan keyakinan seseorang bahwa menaati hukum bukan hanya karena takut disebabkan sanksi, akan tetapi didasarkan oleh keyakinan bahwa apabila ia melanggar hukum, maka ia merasakan adanya pelanggaran terhadap hak-hak manusia lain ${ }^{5}$. Ketika hukum dan moralitas bertentangan satu sama lain, warga negara dihadapkan pada pilihan pahit dengan kehilangan cita rasa moral mereka atau kehilangan penghormatan mereka kepada hukum. Dua keburukan ini memiliki dampak yang sama dan akan sulit bagi seseorang untuk memilih di antara keduanya6.

Salah satu amanat yang terkandung dalam UUD 1945 adalah pemerintah dan seluruh unsur masyarakat wajib melakukan perlindungan dan pengelolaan lingkungan hidup dalam pelaksanaan pembangunan berkelanjutan agar

\footnotetext{
${ }^{1}$ Evi Hartanti, Tindak Pidana Korupsi, Cet. 6, Sinar Grafika, Jakarta, 2016, hlm. 1.

2 Soeroso, Pengantar Ilmu Hukum, Sinar Grafika, Jakarta, 2013, hlm. 52. Muhammad Luthfan Hadi Darus, "Constitutionality in Production Sharing Contracts: Legal Policy on Petroleum and Natural Gas", 2 (1) Prophetic Law Review 74, 2020, hlm. 75.

${ }^{3}$ Erdiansyah, "Kekerasan Dalam Penyidikan Dalam Perspektif Hukum dan Keadilan", Jurnal Imu Hukum Riau, Volume 1, No. 1, 2010, hlm. 132.

${ }^{4}$ M. Ali Zidan, Menuju Pembaharuan Hukum Pidana, Sinar Grafika, Jakarta, 2015, hlm. 110.

5 Waluyadi, Kejahatan, Pengadilan dan Hukum Pidana, Mandar Maju, Bandung, 2009, hlm. 98.

${ }^{6}$ Frederic Bastiat, Hukum, Rancangan Klasik Untuk Membangun Masyarakat Merdeka, Freedom Institute, Jakarta, 2010, hlm. 9.
} 
lingkungan hidup Indonesia tetap menjadi sumber daya dan penunjang hidup bagi rakyat Indonesia serta makhluk hidup lainnya. ${ }^{7}$ Perbuatan-perbuatan yang tidak terpuji sering muncul yang mayoritas disebabkan oleh pendapatan yang tidak sebanding dengan kebutuhan hidup. Selain itu, masa sekarang masyarakat cenderung bersifat materialistis dan ingin hidup kaya. ${ }^{8}$

Manusia dalam menjalani kehidupannya sehari-hari sering dihadapkan kepada kebutuhan yang mendesak, kebutuhan pemuas diri, dan bahkan kadangkadang karena keinginan atau desakan untuk mempertahankan status diri. Kebutuhan setiap manusia secara umum akan dapat dipenuhi, walaupun tidak seluruhnya. Kebutuhan yang mendesak pemenuhannya dan harus dipenuhi dengan segera biasanya sering dilaksanakan tanpa pemikiran matang yang dapat merugikan lingkungan atau manusia lain. ${ }^{9}$

Kerusakan dan/atau pencemaran lingkungan akibat perbuatan manusia sebenarnya merampas, menafikan, atau menghilangkan hak generasi mendatang untuk menikmati lingkungan yang bersih dan sehat seperti merusak fungsi ekologi dan kesehatan ekosistem dalam banyak cara. ${ }^{10}$ Hal ini seperti terjadi di Kecamatan Singingi dimana banyak pertambangan emas tanpa izin yang dilakukan. Kegiatan tersebut memberi dampak yang cukup besar bagi kehidupan dan kelangsungan hidup masyarakat Kecamatan Singingi. Dampak positif yang dirasakan adalah pertumbuhan ekonomi yang mulai stabil sejak adanya pertambangan emas tanpa izin ini. Di sisi lain, dampak negatif yang dirasakan adalah rusaknya lingkungan terutama ekosistem air yang menjadi tercemar akibat pertambangan emas tanpa izin ini, sungai yang tidak dapat dipergunakan untuk kebutuhan sehari-hari karena tidak sehat dan mengandung zat-zat kimia lainnya serta perubahan warna sungai yang tidak jernih lagi atau sudah berubah warna seperti coklat susu akibat aktivitas penambangan emas tanpa izin ini. Peristiwa ini membuktikan bahwa perlu adanya penegakan hukum atas pertambangan emas tanpa izin yang harusnya menjadi hal yang sangat penting untuk lebih diperhatikan, mengingat ada dua aspek penting yang harus diperhitungkan di dalamnya, yaitu aspek ekonomi dan aspek lingkungan.

\section{Rumusan Masalah}

Berdasarkan uraian tersebut di atas, rumusan masalah penelitian ini yaitu, pertama, bagaimanakah penegakan hukum terhadap pertambangan emas tanpa izin oleh Kepolisian Sektor Kecamatan Singingi? Kedua, apa hambatan dalam

\footnotetext{
${ }^{7}$ Helmi, Hukum Perizinan Lingkungan Hidup, Sinar Grafika, Jakarta, 2012, hlm. 1.

${ }^{8}$ Gatot Supramono, Tindak Pidana Korupsi di Bidang Perkeditan, Alumni, Bandung, 1997, hlm. 3.

9 Teguh Prasetyo, Hukum Pidana, Rajawali Pers, Jakarta, 2014, hlm. 3.

${ }^{10}$ Mahrus Ali, Isu-Isu Kontemporer Hukum Pidana, UII Press, Yogyakarta, 2019, hlm. 146.
} 
penegakan hukum terhadap pertambangan emas tanpa izin oleh Kepolisian Sektor Kecamatan Singingi?

\section{Tujuan Penelitian}

Berdasarkan rumusan permasalahan yang telah dipaparkan diatas, tujuan penelitian ini adalah pertama, untuk mengetahui penegakan hukum terhadap pertambangan emas tanpa izin oleh Kepolisian Sektor Kecamatan Singingi, dan kedua, untuk mengetahui hambatan dalam penegakan hukum terhadap pertambangan emas tanpa izin oleh Kepolisian Sektor Kecamatan Singingi.

\section{Metode Penelitian}

Penelitian ini merupakan penelitian yuridis empiris atau penelitian hukum sosiologis yaitu penelitian yang dilakukan dengan cara mengadakan identifikasi hukum dan bagaimana efektifitas hukum itu berlaku. Penelitian ini didukung dengan adanya data empiris, yaitu hasil wawancara dengan narasumber.

\section{Hasil Penelitian dan Pembahasan}

Penegakan Hukum terhadap Pertambangan Emas Tanpa Izin oleh Kepolisian Sektor Kecamatan Singingi

Penegakan hukum merupakan aktualisasi dari tujuan hukum yang masih berada dalam tahap cita-cita dan diwujudkan secara nyata dalam kehidupan masyarakat sesuai dengan cita-cita atau tujuan hukum itu sendiri. Tujuan hukum pada hakikatnya adalah untuk menyatakan sesuatu aturan untuk menjamin kepastian hukum itu. Di samping itu, selain untuk menjamin kepastian hukum juga untuk menjaga rasa keadilan masyarakat yang mengharapkan adanya keadilan hukum itu sendiri. Tidak kalah pentingnya bahwa di samping untuk menjaga kepastian dan keadilan hukum, juga berkepentingan untuk memperoleh kemanfaatan hukum demi menata kehidupan sosial masyarakat. ${ }^{11}$

Secara konsepsional, inti dan arti penegakan hukum terletak pada kegiatan menyerasikan hubungan nilai-nilai yang terjabarkan di dalam kaidah-kaidah yang mantap dan mengejawantah dan sikap tindak sebagai rangkaian penjabaran nilai tahap akhir, untuk menciptakan, memelihara, dan mempertahankan kedamaian pergaulan hidup. ${ }^{12}$ Penegakan hukum harus memperhatikan 3 unsur, yaitu kepastian hukum, kemanfaatan hukum, dan keadilan hukum. Masyarakat

11 Siswanto Sunarso, Viktimologi dalam Sistem Peradilan Pidana, ed. by Tarmizi dan Suryani, edisi 1, Sinar Grafika, Jakarta, 2015, hlm. 83.

12 Soerjono Soekanto, Faktor-Faktor Yang Mempengarubi Penegakan Hukum, Ed. 1, Rajawali Pers, Jakarta, 2016, hlm. 5. 
mengharapkan adanya kepastian hukum, karena dengan adanya kepastian hukum, masyarakat akan lebih tertib. Hukum bertugas menciptakan kepastian hukum karena bertujuan menciptakan ketertiban masyarakat. Sebaliknya, masyarakat mengharapkan kemanfaatan dalam pelaksanaan atau penegakan hukum. Hukum adalah untuk manusia sehingga penegakan hukum harus memberikan kemanfaatan atau kegunaan bagi masyarakat. Artinya, jangan sampai karena hukumnya ditegakkan, timbul keresahan dalam masyarakat ${ }^{13}$. Unsur yang terakhir adalah keadilan, yang berarti bahwa penegakan hukum harus dilakukan dengan mnejunjung tinggi keadilan meskipun hukum tidak identik dengan keadilan. ${ }^{14}$

Ada beberapa faktor-faktor yang mempengaruhi penegakan hukum. Faktor tersebut cukup mempunyai arti sehingga dampak positif dan negatifnya terletak pada isi faktor tersebut. Menurut Soerjono Soekanto bahwa faktor-faktor tersebut ada lima, yaitu pertama, hukumnya sendiri, yang di dalam tulisan ini akan dibatasi pada undang-undang saja, kedua, penegak hukum, yakni pihak-pihak yang membentuk maupun menerapkan hukum, ketiga, sarana atau fasilitas yang mendukung penegakan hukum, keempat, masyarakat, yakni lingkungan dimana hukum tersebut berlaku atau diterapkan, dan kelima kebudayan, yakni hasil karya, cipta, dan rasa yang didasarkan pada karsa manusia di dalam pergaulan hidup. ${ }^{15}$

Penegakan hukum tindak pidana pertambangan emas tanpa izin di Kecamatan Singingi masih belum optimal mengingat masih banyak kasus yang belum diproses oleh aparat penegak hukum meskipun angka kasusnya masih cukup tinggi. Bahkan, bisa dikatakan hampir tidak tersentuh hukum meskipun dampak yang ditimbulkan dirasakan langsung dan kegiatan penambangan emas tanpa izin (PETI) dilakukan secara terang-terangan. Berikut adalah beberapa kasus yang pernah diproses kurun waktu 3 tahun terakhir:

Tabel Data Beberapa Kasus Pertambangan Emas Tanpa Izin yang Berhasil Diproses oleh Kepolisian Sektor Singingi Tahun 2018-2020

\begin{tabular}{lllllr}
\hline No & Laporan Polisi dan Tanggal & \multicolumn{1}{c}{ Tersangka } & \multicolumn{1}{c}{ Tkp } & Ket \\
\hline 1. & LP.A/03/I/2018/RIAU/RE & Heru Budiono Als & Desa Logas & P-21 \\
& SKRIM 17 Januari 2018 & Gundui Bin Deman & Kec. & \\
& & Ttl:Pati/25 Desember & Singingi & \\
& 1990 & Kab. & \\
& Islam, Buruh & Kuansing & \\
& Kel. Muara Lembu & & \\
& Kec. Singingi & & \\
& Kab. Kuansing & & \\
\hline
\end{tabular}

${ }^{13}$ John Thamrun, Persilisiban Prayudisial: Penundaan Pemeriksaan Perkara Pidana Terkait Perkara Perdata, Sinar Grafika, Jakarta, 2016, hlm. 18.

${ }^{14}$ Ibid, hlm. 19.

15 Ishaq, Dasar-Dasar Ilmu Hukum, ed. by Yunasril Ali, Revisi, Sinar Grafika, Jakarta, 2016, hlm. 298-299. 
2. LP.A/07/2018/RIAU/RESK RIM 26 Februari 2018

$\begin{array}{lll}\text { Supardi Als Pardi Bin } & \text { Kel. Muara } & \text { P-21 } \\ \text { Sumardi } & \text { Lembu } & \\ \text { Tt1: Medan/21-07- } & \text { Kec. } & \\ \text { 1979, Islam, Buruh } & \text { Singingi } & \\ \text { Kel. Muara Lembu } & \text { Kab. } & \\ \begin{array}{l}\text { Kec. Singingi } \\ \text { Kab. Kuansing }\end{array} & \text { Kuansing } & \\ \text { Yonis Dan Yuri Asta } & \text { Kel. Muara } & \text { P-21 } \\ & \text { Lembu } & \\ & & \\ \text { Nofriyon } & & \text { P-21 } \\ & & \\ & & \end{array}$

3. LP.A/06/II/2019/RIAU/Re s Kuansing/Polsek Singingi, tanggal $26 \quad$ Februari 2019.PETI.

4. LP.A/21/X/2019/Riau/Res Kuansing/Sek Singingi, tanggal 23 Oktober 2019.PETI.

Sumber: Kanit Reskrim Kepolisian Sektor Singingi, 21 September 2020

Polisi merupakan unsur utama atau perangkat awal dalam proses penegakan hukum. Polisi berperan menentukan suatu perbuatan pidana beserta bukti pendukung dalam melaksanakan kegiatan penanggulangan kejahatan untuk mewujudkan situasi Kamtibnas (Keamanan dan Ketertiban Masyarakat) terkendali dalam wadah kepolisian Republik Indonesia. Pasal 13 Undang-Undang Nomor 2 Tahun 2002 tentang Kepolisian mengatur bahwa tugas pokok polisi adalah memelihara keamanan dan ketertiban masyarakat, menegakkan hukum, dan memberikan perlindungan, pengayoman, dan pelayanan kepada masyarakat.

Pengertian penegakan hukum dapat dirumuskan sebagai usaha melaksanakan hukum sebagaimana mestinya, mengawasi pelaksanaannya agar tidak terjadi pelanggaran, dan jika terjadi pelanggaran memulihkan hukum yang dilanggar itu supaya ditegakkan kembali. Penegakan hukum dilakukan dengan penindakan hukum dengan tahapan yaitu teguran peringatan supaya menghentikan pelanggaran dan jangan berbuat lagi (percobaan), pembebanan kewajiban tertentu (ganti kerugian, denda), penyisihan atau pengucilan (pencabutan hak-hak tertentu), pengenaan sanksi badang (pidana penjara, pidana mati). ${ }^{16}$

Keberadaan PETI di Kecamatan Singingi mempunyai dampak positif secara ekonomi, yaitu menciptakan lapangan pekerjaan yang kemudian sangat berpengaruh terhadap perkembangan ekonomi masyarakat. Akan tetapi, dalam perkembangannya PETI juga banyak menimbulkan beberapa dampak negatif di antaranya yaitu pertama, terjadinya kerusakan lingkungan sebagai akibat dari pengelolaan bahan galian yang digunakan akan merusak ekosistem air dimana

16 Abdulkadir Muhammad, Etika Profesi Hukum, PT. Citra Aditya Bakti, Bandung, 2001, hlm. 115. 
sungai menjadi tercemar akibat zat atau bahan kimia yang digunakan dalam pengelolaannya sehingga air sungai dapat digunakan untuk kebutuhan seharihari dan ikan-ikan di dalamnya juga menjadi berbahaya untuk dikonsumsi. Hal ini tidak lain karena dampak pencemaran melalui zat atau bahan kimia yang digunakan. Selain itu, akibat yang ditimbulkan oleh PETI juga dirasakan warga ketika musim hujan, yaitu banyak daerah di pinggiran sungai terkena banjir sebagai akibat tidak adanya pohon-pohon yang memadai untuk menyerap air di kala volume air meningkat pada saat musim hujan.

Kedua, perlindungan kesehatan menjadi terabaikan akibat pencemaran dari penggunaan zat atau bahan kimia berbahaya dalam pengelolaan PETI. Selain itu, lubang yang disebabkan oleh hasil galian PETI menjadi sangat berbahaya, karena tidak sedikit para pekerja meninggal dunia karena tenggelam dalam lobang bekas galian PETI. Ketiga, terjadinya pelanggaran terhadap sistem perpajakan resmi. Selain pelanggaran terhadap izin pertambangan, transaksi penjualan emas secara ilegal pun banyak terjadi.

Hukum pidana sebagai salah satu instrument penegakan hukum permasalahan tersebut, yang bukan merupakan kejahatan konvensional sehingga sulit terdeteksi karena modus operandi-nya yang sangat kompleks dan melibatkan orang-orang yang memiliki pengaruh dalam jabatan penting, ${ }^{17}$ diharapkan dapat berperan secara efektif. Kepentingan ekonomi dan politik sangat besar peranannya dalam kegiatan penambangan emas tanpa izin dimana terdapat pihak-pihak yang meraih keuntungan penambangan emas illegal, baik masyarakat penambangan dengan pemodal, pemodal dengan aparat penegak hukum, dan pemerintah yang membuat larangan atau kebijakan. Hal ini tentu saja berdampak pada praktekpraktek eksploitasi sumber daya alam yang dilakukan oleh masyarakat atau kelompok individu yang berkepentingan. Pihak yang meraih keuntungan tidak hanya diperoleh oleh kelompok penambang, akan tetapi juga terdapat pihak yang memiliki kekuatan untuk melindungi pelaku PETI.18

Pertambangan emas tanpa izin sudah jelas merupakan perbuatan yang dilarang oleh undang-undang. Masyarakat yang terkena dampak berhak untuk mendapatkan hidup yang sejahtera lahir dan batin, bertempat tinggal, dan mendapatkan lingkungan hidup yang baik dan sehat, serta berhak memperoleh pelayanan kesehatann sebagaimana yang telah tercantum dalam Pasal 28H ayat

17 Mahrus Ali, Dasar-Dasar Hukum Pidana, Sinar Grafika, Jakarta, 2015, hlm. 247. Dodik Setiawan Nur Heriyanto, "Resolving Indonesia's Responsibility for Transboundary Haze Pollution in Light of the Toothless ATHP”, Hungarian Yearbook of International Law and European Law 191, 2017, hlm. 193-196.

18 Dona Fauziah and Ishak Ishak, 'Ekonomi Politik: Relasi Pemerintah Daerah Dan Masyarakat Dalam Kasus Pertambangan Emas Tanpa Izin Di Desa Petapahan Kecamatan Gunung Toar Kabupaten Kuantan Singingi Tahun 2013-2015', JOM FISIP, Volume 4, 2017, hlm. 4. 
(1) UUD NRI 1945. Selain itu, Undang-Undang Nomor 32 Tahun 2009 tentang Perlindungan dan Pengelolaan Lingkungan Hidup (Undang-Undang PPLH) juga mengatur mengenai larangan pertambangan emas tanpa izin (PETI). Pasal 3 Undang-Undang PPLH menyatakan bahwa perlindungan dan pengelolaan lingkungan hidup bertujuan untuk melindungi wilayah negara kesatuan republik indonesia dari pencemaran dan/atau kerusakan lingkungan hidup, menjamin keselamatan, kesehatan, dan kehidupan manusia, serta menjamin kelangsungan kehidupan makhluk hidup dan kelestarian ekosistem.

Pasal 3 tersebut juga mengatur bahwa perlindungan dan pengelolaan lingkungan hidup bertujuan untuk menjaga kelestarian fungsi lingkungan hidup, mencapai keserasian, keselarasan, dan keseimbangan lingkungan hidup, menjamin terpenuhinya keadilan generasi masa kini dan generasi masa depan, menjamin pemenuhan dan perlindungan hak atas lingkungan hidup sebagai bagian dari hak asasi manusia, mengendalikan pemanfaatan sumber daya alam secara bijaksana, Mewujudkan pembangunan berkelanjutan, dan Mengantisipasi isu lingkungan global.

Undang-Undang PPLH juga mengatur ketentuan pidana bagi pelaku pencemaran lingkungan hidup sebagaimana diatur dalam Pasal 98 yang menyatakan bahwa ancaman pidana bagi setiap orang yang dengan sengaja melakukan perbuatan yang mengakibatkan dilampauinya baku mutu udara ambien, baku mutu air, baku air laut, atau kriteria baku kerusakan lingkungan hidup, adalah pidana penjara, paling singkat 3 tahun dan paling lama 10 tahun, dan denda paling sedikit Rp. 3.000.000.000,00 dan paling banyak Rp. 10.000.000.000,00. Ayat (2) pasal tersebut menerangkan bahwa apabila perbuatan tersebut mengakibatkan orang luka dan/atau bahaya kesehatan manusia, ancaman pidananya yaitu pidana penjara, paling singkat 4 tahun dan paling lama 12 tahun, dan denda paling sedikit Rp. 4.000.000.000,00 dan paling banyak Rp. 12.000.000.000,00. Apabila perbuatan tersebut mengakibatkan orang luka berat atau mati, ancaman pidananya adalah pidana penjara paling singkat 5 tahun dan paling lama 15 tahun dan denda paling sedikit Rp. 5.000.000.000,00 dan paling banyak Rp. 15.000.000.000,00."

Penelitian di lapangan diketahui beberapa fakta yaitu ada serangkaian aktivitas Pertambangan Emas Tanpa Izin (PETI) yang tidak terkendali yang dilakukan oleh masyarakat untuk memenuhi kebutuhan hidup sehari-hari, banyaknya kerusakan lingkungan berupa pencemaran daerah aliran sungai, lahan bekas tambang serta rusaknya ekosistem alam diakibatkan aktifitas PETI tersebut, dan kurang efektifnya kinerja pemerintah dalam melakukan 
pengendalian PETI yang menyebabkan aktivitas PETI masih berjalan sampai saat ini dan menimbulkan kerusakan lingkungan yang lebih parah lagi. ${ }^{19}$

Hasil wawancara dengan penyidik menunjukkan bahwa dalam penegakan hukum penambangan emas tanpa izin ada beberapa upaya yang dapat dilakukan yaitu upaya preventif dan upaya represif. ${ }^{20}$ Upaya Preventif, yaitu upaya pencegahan terhadap suatu tindak pidana sebelum tindak pidana itu dilakukan atau terjadi. Upaya penanggulangan dengan cara ini tidak memakai sarana pidana, tapi berusaha memanfaatkan potensi-potensi di dalam masyarakat secara terpadu. ${ }^{21}$ Ada beberapa upaya preventif yang dilakukan yaitu ${ }^{22}$ melakukan himbauan mengenai PETI kepada masyarakat yaitu seperti dalam melakukan suatu pertambangan harus mendapatkan izin dari Dinas Pertambangan,dan melakukan razia secara berkala yaitu merupakan salah satu upaya yang efektif dalam mencegah terjadinya gangguan yang ada di masyarakat. Terkait hal ini, aparat kepolisian langsung terjun ke lapangan atau lokasi pertambangan emas tanpa izin.

Upaya Represif adalah tindakan represif (penindakan) terhadap pelaku penambangan emas tanpa izin di Kecamatan Singingi. Dalam hal ini, sudah ada beberapa kasus yang berhasil dilakukan penangkapan atau penertiban terhadap para pelaku PETI. Adapun tindakan yang dilakukan oleh pihak kepolisian adalah pertama, adanya laporan atau informasi dari masyarakat bahwa terdapat lokasi di wilayah hukum Polsek Singingi telah terjadi pertambangan emas tanpa izin. ${ }^{23}$ Kedua, melakukan penyelidikan sebagai langkah awal atau upaya awal untuk mengidentifikasi benar dan tidaknya suatu peristiwa pidana itu terjadi. ${ }^{24}$ Ketiga, tahap penyidikan dimana penyidikan tindak pidana pada hakikatnya merupakan wujud penegakan hukum yang diatur dalam perundang-undangan mengingat tugas penyidikan tindak pidana berkaitan dengan hak asasi manusia. Polri sebagai alat negara penegak hukum, pelindung, pengayom masyarakat berkewajiban untuk memelihara tegaknya hukum, keadilan, dan perlindungan terhadap harkat dan martabat manusia serta ketertiban dan kepastian hukum. ${ }^{25}$

Keempat, melaksanakan penangkapan yang didasarkan atas Pasal 18 Kitab Undang-Undang Hukum Acara Pidana. Setelah penangkapan dilakukan maka

\footnotetext{
19 Putra Mido, 'Kebijakan Pemerintah Kabupaten Kuantan Singingi Dalam Pengendalian Kerusakan Lingkungan Hidup Akibat Pertambangan Emas Tanpa Izin (PETI)', JOM FISIP, Volume 3, 2016, hlm. 5.

${ }^{20}$ Hasil wawancara pada 21 September 2020, bersama Kanit Reskrim Polsek Singingi AIPDA Merian Donal.

21 Teddy Guntara, R Mukhlis, and Widia Edorita, 'Penegakan Hukum Tindak Pidana Perjudian Online Di Kota Pekanbaru', Riau University, 2014, hlm. 9.

22 Hasil wawancara pada 21 September 2020, bersama Kanit Reskrim Polsek Singingi AIPDA Merian Donal

${ }^{23}$ Hasil wawancara pada 21 September 2020, bersama Kanit Reskrim Polsek Singingi AIPDA Merian Donal.

${ }^{24}$ Hartono, Penyidikan \& Penegakan Hukum Pidana, Cet. 2 edn, Sinar Grafika, Jakarta, 2012, hlm. 18.

25 I Ketut Adi Purnama, Transparansi Penyidik Polri Dalam Sistem Peradilan Pidana Di Indonesia, PT Refika Aditama, Bandung, 2018, hlm. 70.
} 
petugas pelaksana membuat Berita Acara Penangkapan berdasarkan Pasal 75 ayat (1). Kelima, melakukan penahanan yaitu upaya paksa, tidak dengan sendirinya menghilangkan harkat dan martabat tersangka, tidak pula dapat melenyapkan hak-hak asasi yang melekat pada dirinya secara keseluruhan. ${ }^{26}$ Setiap penahanan wajib dilaksanakan berdasarkan surat perintah penahanan yang dikeluarkan oleh penyidik atau atasan penyidik selaku penyidik.

Keenam, melakukan penyitaan penyidik yang dilengkapi dengan surat perintah tugas dan surat perintah penyitaan. Dalam hal tertangkap tangan, penyidik dapat menyita benda dan alat yang ternyata atau yang patut diduga telah dipergunakan untuk melakukan tindak pidana atau benda lain yang dapat dipakai sebagai barang bukti. Terakhir, menyerahkan berkas kepada pihak kejaksaan dilakukan oleh aparat kepolisian setelah berkas perkara dinyatakan lengkap, dengan penyerahan berkas tersebut juga merupakan penyerahan tanggung jawab terhadap tersangka dan barang bukti.

Peranan aparatur pemerintah terutama instansi yang menangani langsung tentang masalah hukum perlu meningkatkan pola kerjanya secara terus menerus sehingga dapat mencapai hasil guna dengan tingkat yang maksimal. ${ }^{27}$ Hukum yang baik tentunya tidak akan ada gunanya apabila tidak ditegakkan. Oleh karena itu, dibutuhkan sumber daya yang berkualitas dan sarana atau prasarana yang mendukungnya. Di samping itu, dukungan masyarakat luas merupakan prasyarat untuk terwujudnya penegakan hukum yang berkeadilan. ${ }^{28}$

Penegakan hukum tidak dapat dilepaskan dari fundamental hukumnya sendiri, yaitu tercapainya keadilan dan kemanfaatan sosial. Keadilan salah satunya dapat terwujud apabila terhadap pelaku diberi ganjaran yang setimpal dengan perbuatannya (prinsip individualisasi pidana). Dengan demikian, bukan pidana yang sama terhadap perbuatan yang sama namun tindakan hukum apa yang tepat dijatuhkan kepada pelaku kejahatan berdasarkan motif dilakukannya perbuatan tersebut, keadaan lingkungan, maupun karakteristik pelaku sendiri ${ }^{29}$.

\section{Hambatan dalam Penegakan Hukum terhadap Pertambangan Emas Tanpa Izin di Kabupaten Kuantan Singingi}

Perilaku yang tidak sesuai norma atau dapat disebut sebagai penyelewengan terhadap norma yang telah disepakati menyebabkan terganggunya ketertiban dan ketentraman kehidupan manusia. Penyelewengan

${ }^{26}$ Suharto dan Jonaedi Efendi, Panduan Praktis Bila Anda Menghadapi Perkara Pidana, PT. Prestasi Pustakaraya, Jakarta, 2010, hlm. 74.

27 Ilham Gunawan, Penegak. Hukum Dan Penegakan Hukum, Angkasa, Bandung, 1993, hlm. 2.

${ }^{28}$ M. Ali Zidan, Kebijakan Kriminal, Sinar Grafika, Jakarta, 2016, hlm. 278.

${ }^{29}$ Ibid., hlm. 284. 
yang demikian biasanya oleh masyarakat dicap sebagai suatu pelanggaran dan bahkan sebagai suatu kejahatan, baik dalam kehidupan manusia, masyarakat, dan bahkan negara. Kenyataan telah membuktikan bahwa kejahatan hanya dapat dicegah dan dikurangi, tetapi sulit diberantas secara tuntas. ${ }^{30}$ Elemen dasar dari penegakan hukum pidana seharusnya merupakan proses penemuan fakta yang tidak memihak (impartial) dan penuh dengan resolusi atau pemecahan masalah yang harus dilakukan secara adil (fair) dan patut (equitable). Apapun teori keadilan yang dipakai, defenisi keadilan harus mencakup kejujuran (fairness), tidak memihak (impartiality), serta pemberian sanksi dan hadiah yang patut (appropriate reward and punishment). ${ }^{31}$

Ada beberapa kendala ataupun hambatan dalam penegakan hukum tindak pidana pertambangan emas tanpa izin yang dilakukan oleh Polsek Singingi yaitu ${ }^{32}$ pertama terbatasnya sarana dan prasarana pendukung. Lokasi penambangan yang jauh dan sulit dijangkau sehingga mengakibatkan proses pencarian barang bukti sulit ditemukan. Keadaan demikian ditandai dengan sulitnya akses kendaraan menuju tempat lokas, baik menggunakan roda empat atau roda dua. Selain itu, proses pertambangan emas tanpa izin juga dilakukan di hutan-hutan dan tidak jarang juga dalam penyelidikan harus berjalan kaki berkilo-kilo meter.

Kedua, kurangnya kepedulian dan kesadaran hukum masyarakat. Salah satu pemicu yang dapat menghambat kerja aparat kepolisian dalam mengungkap kasus pertambangan emas tanpa izin ini adalah kurangnya kepedulian dan kesadaran masyarakat. Banyak dampak negatif yang dirasakan oleh masyarakat akibat pertambangan emas tanpa izin ini. Tetapi karena alasan ekonomi terkadang masyarakat buta akan dampak-dampak negatif tersebut. Seringkali karena alasan ekonomi, setelah masyarakat tertangkap mereka juga akan kembali melakukan hal yang sama setelah mereka bebas. Ketiga, koordinasi dengan pemerintah, yiatu belum ada solusi dari pemerintah mengenai masalah pertambangan emas tanpa izin, karena salah satu yang diharapkan oleh para pekerja PETI adalah mendapatkan izin dari pamerintah. Karena bagaimanapun masyarakat atau pekerja PETI melakukan PETI untuk penghidupan atau penunjang ekonomi, karena memang terbukti PETI dapat menunjang perekonomian masyarakat pekerja PETI.

Hambatan-hambatan yang dihadapi oleh Kepolisian Resor Kabupaten Kuantan Singingi di atas menunjukkan bahwa penegakan hukum di wilayah hukum Kepolisian Sektor Kecamatan Singingi masih belum bisa dikatakan

\footnotetext{
${ }^{30}$ Bambang Waluyo, Pidana Dan Pemidanaan, Cet. 4 edn, Sinar Grafika, Jakarta, 2014, hlm. 1.

31 Siswanto Sunarso, Op. Cit., hlm. 83-84.

32 Hasil wawancara pada 21 September 2020, bersama Kanit Reskrim Polsek Singingi AIPDA Merian Donal
} 
berhasil karena berdasarkan hasil pengamatan dan fakta di lapangan masih banyak penambangan emas tanpa izin yang terjadi. Bahkan, kegiatan PETI ini bukan hanya dilakukan di sungai saja, tetapi sudah merambat ke perkebunan warga atau hutan-hutan belantara.

Para pemilik penambangan emas tanpa izin akan membeli atau menyewa atau bekerja sama dengan pemilik lahan untuk melakukan penambangan emas tanpa izin ini kemudian keuntungan atau hasil akan dibagi sesuai dengan kesepakatan. Jadi, selain ekosisitem air sungai yang telah tercemar, ekosistem hutan pun kini mulai terancam oleh kegiatan penambangan emas tanpa izin ini. Pada akhirnya hal ini juga akan berpengaruh pada pemanasan global mengingat hutan merupakan pembatu menyerap gas rumah kaca yang menjadi penyebab terjadinya pemanasan global.

Berdasarkan hasil pengamatan, selain hambatan-hambatan yang dialami oleh pihak Kepolisian Sektor Singingi, ada hambatan lain yang juga mempengaruhi lambatnya atau terkendalanya penegakan hukum di wilayah hukum Polsek Singingi yaitu kurangnya penegakan hukum adat oleh para ketua adat dalam menjaga lingkungan dan melindungi masyarakat adat. Hal ini didasarkan bahwa wilayah hukum Polsek Singingi juga masih sangat kental dengan hukum adat namun dalam hal pertambangan emas tanpa izin, hukum adat seakan tak mampu menjawab persoalan yang sedang terjadi. Padahal jika dilihat dampak yang telah ditimbulkan juga sudah meresahkan dan berdampak langsung bagi warga yang hidup tidak jauh dari perairan atau sungai. Oleh sebab itu, hal tersebut seharusnya menjadi perhatian besar oleh pemerintah dalam menanggulangi dan menemukan solusi terbaik untuk masalah kasus penambangan emas tanpa izin yang semakin merajalela. Hal ini disebabkan karena kegiatan PETI memiliki dampak positif yang cukup tinggi terutama di bidang peningkatan perekonomian namun di sisi lain juga mempunyai dampak negatif yang dapat mempengaruhi keberlangsungan kehidupan dan ekosistem generasi yang akan datang.

\section{Penutup}

Pemaparan hasil penelitian diatas menunjukkan bahwa kasus tindak pidana pertambangan emas tanpa izin (PETI) di Kecamatan Singingi masih cukup tinggi yang diantaranya masih banyak kasus yang belum diproses oleh aparat penegak hukum meskipun dampak yang ditimbulkan dapat dirasakan secara langsung dan kegiatan PETI tersebut dilakukan secara terang-terangan. Kegiatan PETI di Kecamatan Singingi mempunyai dampak positif seperti menciptakan lapangan pekerjaan yang kemudian sangat berpengaruh terhadap perkembangan ekonomi masyarakat. Tetapi di sisi lain, PETI juga banyak menimbulkan dampak negatif di 
antaranya kerusakan lingkungan, perlindungan kesehatan menjadi terabaikan, pelanggaran terhadap sistem perpajakan resmi.

Beberapa upaya yang dilakukan untuk melakukan penegakan hukum tindak pidana penambangan emas tanpa izin yaitu pertama upaya preventif berupa melakukan himbauan dan melakukan razia berkala. Kedua, upaya represif yang diawali dengan adanya informasi atau laporan, penyelidikan, penyidikan, penangkapan, penahanan, penyitaan, dan penyerahan berkas perkara. Selain itu, ada beberapa hambatan dalam penegakan hukum tindak pidana pertambangan emas tanpa izin ini yaitu terbatasnya sarana dan prasarana pendukung, kurangnya kepedulian dan kesadaran hukum masyarakat, masalah koordinasi dengan pemerintah. Hambatan-hambatan yang dihadapi oleh Kepolisian Resor Kabupaten Kuantan Singingi tersebut menunjukkan bahwa penegakan hukum di wilayah hukum Kepolisian Sektor Kecamatan Singingi masih belum bisa dikatakan berhasil. Selain itu, hambatan yang mempengaruhi lambatnya atau terkendalanya penegakan hukum di wilayah hukum Polsek Singingi adalah kurangnya penegakan hukum adat oleh para ketua adat dalam menjaga lingkungan dan melindungi masyarakat adat meskipun di wilayah hukum Polsek Singingi masih sangat kental dengan hukum adat.

\section{Daftar Pustaka}

\section{Buku}

Ali, Mahrus, Dasar-Dasar Hukum Pidana, Sinar Grafika, Jakarta, 2015. Isu-Isu Kontemporer Hukum Pidana, UII Press, Yogyakarta, 2019.

Bastiat, Frederic, Hukum, Rancangan Klasik Untuk Membangun Masyarakat Merdeka, Freedom Institute, Jakarta, 2010.

Hartanti, Evi, Tindak Pidana Korupsi, Cet. 6, Sinar Grafika, Jakarta, 2016.

Hartono, Penyidikan \& Penegakan Hukum Pidana, ed. by Leny Wulandari, 1st, Cet. 2, Sinar Grafika, Jakarta, 2012.

Helmi, Hukum Perizinan Lingkungan Hidup, Sinar Grafika, Jakarta, 2012.

Ishaq, Dasar-Dasar Ilmu Hukum, ed. by Yunasril Ali, Revisi, Ce, Sinar Grafika, Jakarta, 2016.

Muhammad, Abdulkadir, Etika Profesi Hukum, PT. Citra Aditya Bakti, Bandung, 2001.

Prasetyo, Teguh, Hukum Pidana, Rajawali Pers, Jakarta, 2014.

Purnama, I Ketut Adi, Transparansi Penyidik Polri Dalam Sistem Peradilan Pidana Di Indonesia, ed. by Nurul Falah Atif, Cetakan Ke, PT Refika Aditama, Bandung, 2018.

Soekanto, Soerjono, Faktor-Faktor Yang Mempengaruhi Penegakan Hukum, Ed. 1, Cet Rajawali Pers, Jakarta, 2016. 
Soeroso, Pengantar Ilmu Hukum, Sinar Grafika, Jakarta, 2013.

Suharto dan Jonaedi Efendi, Panduan Praktis Bila Anda Menghadapi Perkara Pidana, ed. by Fifit Fitri Lutfianingsi, PT. Prestasi Pustakaraya, Jakarta, 2010.

Sunarso, Siswanto, Viktimologi Dalam Sistem Peradilan Pidana, ed. by Tarmizi dan Suryani, edisi 1, Sinar Grafika, Jakarta, 2015.

Supramono, Gatot, Tindak Pidana Korupsi Di Bidang Perkreditan, Alumni, Bandung, 1997.

Thamrun, John, Persilisihan Prayudisial: Penundaan Pemeriksaan Perkara Pidana Terkait Perkara Perdata, Sinar Grafika, Jakarta, 2016.

Waluyadi, Kejahatan, Pengadilan Dan Hukum Pidana, Mandar Maju, Bandung, 2009.

Waluyo, Bambang, Pidana Dan Pemidanaan, ed. by Suwarna, 1st, Cet. 4 edn, Sinar Grafika, Jakarta, 2014.

Zaidan, M. Ali, Menuju Pembaharuan Hukum Pidana, Sinar Grafika, Jakarta, 2015.

Jurnal

Darus, Muhammad Luthfan Hadi, "Constitutionality in Production Sharing Contracts: Legal Policy on Petroleum and Natural Gas", 2 (1) Prophetic Law Review 74, 2020.

Erdiansyah, "Kekerasan Dalam Penyidikan dalam Perspektif Hukum dan Keadilan", Jurnal Ilmu Hukum Riau, 1, 2010.

Fauziah, Dona, and Ishak Ishak, "Ekonomi Politik: Relasi Pemerintah Daerah dan Masyarakat dalam Kasus Pertambangan Emas Tanpa Izin di Desa Petapahan Kecamatan Gunung Toar Kabupaten Kuantan Singingi Tahun 2013-2015", JOM FISIP , 4, 2017.

Guntara, Teddy, R Mukhlis, and Widia Edorita, "Penegakan Hukum Tindak Pidana Perjudian Online di Kota Pekanbaru", Jurnal Riau University, 2014.

N Heriyanto, D Setiawan, “Resolving Indonesia's Responsibility for Transboundary Haze Pollution in Light of the Toothless ATHP", Hungarian Yearbook of International Law and European Law 191, 2017.

Putra Mido, "Kebijakan Pemerintah Kabupaten Kuantan Singingi dalam Pengendalian Kerusakan Lingkungan Hidup Akibat Pertambangan Emas Tanpa Izin (PETI)', JOM FISIP, 3, 2016.

\section{Perundang-Undangan}

Undang-Undang Dasar Negara Republik Indonesia Tahun 1945

Undang-Undang Nomor 32 Tahun 2009 tentang Perlindungan dan Pengelolaan Lingkungan Hidup 